\title{
The role of inflammation in cardiovascular diseases: the predictive value of neutrophil- lymphocyte ratio as a marker in peripheral arterial disease
}

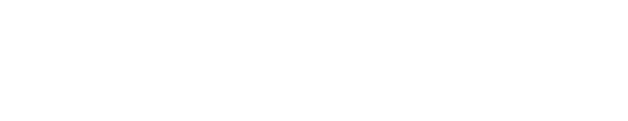

\author{
Feliciano Chanana Paquissi \\ Department of Medicine, Clínica \\ Girassol, Luanda, Angola
}

\begin{abstract}
Peripheral arterial disease (PAD) is an important manifestation of atherosclerosis, with increasing prevalence worldwide. A growing body of evidence shows that the systemic inflammatory response is closely related to the development, progression, and prognosis of atherosclerosis. In the last decade, several studies have suggested the role of measured inflammatory biomarkers as predictors of severity and prognosis in PAD in an effort to stratify the risk of these patients, to improve treatment selection, and to predict the results after interventions. A simple inflammatory marker, more available than any other, is the neutrophil-lymphocyte ratio (NLR), which can be easily obtained in clinical practice, based on the absolute count of neutrophils and lymphocytes from the differential leukocytes count. Many researchers evaluated vigorously the NLR as a potential prognostic biomarker predicting pathological and survival outcomes in patients with atherosclerosis. In this work, we aim to present the role of NLR as a prognostic marker in patients with PAD through a thorough review of the literature.
\end{abstract}

Keywords: neutrophil-lymphocyte ratio, peripheral arterial disease, inflammation, cardiovascular diseases, biomarkers

\section{Introduction}

Peripheral arterial disease (PAD) is an important manifestation of atherosclerosis, which affects $>202$ million people worldwide, ${ }^{1}$ and is associated with cardiovascular events, ${ }^{2}$ with increased all-cause and cardiovascular mortality. ${ }^{3,4}$ PAD, despite the advances registered in its treatment, still has a worse prognosis compared with coronary artery disease $(\mathrm{CAD})^{5}$ by various factors, including the high rate of instent restenosis, which occurs with an important contribution of the inflammatory response. ${ }^{6,7}$ These negative outcomes have brought in sight the need of biomarkers as predictors of outcomes to ensure better risk stratification, proper selection of treatment approaches, and, if necessary, additional multitarget approaches (such as the endovascular brachytherapy). ${ }^{8}$

In recent years, the literature has highlighted the value of systemic inflammation as an important element in the development, progression, and prognosis of atherosclerosis. ${ }^{9}{ }^{10}$ It is worth to mention that PAD is the atherosclerotic manifestation that shows the greater relationship with systemic inflammation. ${ }^{11}$ Several inflammatory markers have been shown to be useful in clinical studies on risk stratification and prognosis of patients with PAD, ${ }^{12,13}$ as well as in those with disease in other vascular beds as cerebral and coronary. ${ }^{14-16}$ 
Among the inflammatory markers, neutrophil-lymphocyte ratio (NLR), defined as the ratio of absolute counts of neutrophils and lymphocytes, has gained space as an effective biomarker in the stratification and prognosis of atherosclerotic cardiovascular disease (CVD), and in particular PAD. ${ }^{17}$ The NLR is a derived marker, simple, relatively inexpensive, more available than any other, and has shown itself to be a good predictor for other multiple cardiovascular outcomes ${ }^{18-20}$ that reflect an imbalance in the inflammatory cells and the role of activated neutrophils in atherogenesis..$^{21,22}$ In a representative sample from the National Health and Nutrition Examination Survey, including 9,427 subjects, the average NLR was 2.15 in the general population, being significantly higher in subjects who reported diabetes, CVD, and smoking than in those who did not. ${ }^{23}$

In this article, we reviewed the clinical studies that evaluated the role of inflammatory biomarkers as predictors of outcomes in patients with PAD, with particular emphasis on NLR.

\section{Prognostic value of inflammatory biomarkers in CVDs in general}

Multiple inflammatory markers such as C-reactive protein (CRP) and interleukin-6 (IL-6) have been associated with cardiovascular events. ${ }^{15,24,25} \mathrm{CRP}$ is associated with CAD, ischemic stroke, and mortality by vascular and nonvascular causes. ${ }^{15,26}$

\section{The NLR as a biomarker in CAD}

On CAD, a high NLR is associated with severity of disease, as was evident in a cohort of 3,005 patients undergoing coronary angiography for several indications, in which those with NLR $>3$ had more advanced obstructive CAD (odds ratio $[\mathrm{OR}] 2.45, P<0.001$ ) and worse prognosis, with higher rates of major cardiovascular events (hazard ratio [HR] 1.55, $P=0.01$ ) within 3 years of follow-up. ${ }^{27}$ NLR is a predictor of mortality in patients with ischemic heart disease both in stable $\mathrm{CAD}^{19}$ and in acute coronary syndrome..$^{20,28,29} \mathrm{~A}$ high NLR at admission for acute coronary syndrome is associated with all-cause in-hospital (OR 2.04, $P=0.013$ ) and 6-month mortality (OR 3.88, $P<0.001) .{ }^{18}$ In treated patients, a high pre-intervention NLR was an independent predictor of instent restenosis after percutaneous coronary intervention (OR 1.85, $P<0.001),{ }^{30}$ saphenous vein graft failure for those undergoing coronary artery bypass grafting, ${ }^{31}$ and cardiovascular mortality. ${ }^{32}$ In a meta-analysis of eight cohort studies with patients undergoing myocardial revascularization or coronarography, a high NLR increased about twice the risk of cardiovascular and all-cause mortality. ${ }^{33}$

\section{The NLR as a biomarker in cerebrovascular disease}

In patients with stroke, the NLR is an independent mortality predictor in the short and long term. ${ }^{34-36}$ An NLR $\geq 5.9$ at admission was associated with significant functional dependence (OR 6.72, $P=0.025$ ) and predicted mortality at 90 days (OR 6.69, $P=0.006$ ) after adjusting for potential confounders. ${ }^{37}$ In those patients with ischemic stroke who underwent carotid ultrasonography, NLR significantly predicted the degree of carotid stenosis in male patients. ${ }^{37}$ In a study in Turkey with patients who presented to the emergency service with cerebrovascular accident (stroke and transient ischemic attack), the NLR was significantly higher in patients who died $(P<0.001)$ and in those with ischemic or hemorrhagic stroke than in those with transient ischemic attack $(P<0.001){ }^{38}$

\section{The NLR as a biomarker in other vascular diseases}

The role of NLR seems to begin even before the occurrence of any target organ damage, as was demonstrated in a cohort in which a higher NLR level significantly correlated with an increased risk of developing hypertension compared to participants with lower levels (OR 1.23; 95\% confidence interval $[\mathrm{CI}] 1.06,1.43) .{ }^{39}$ In other studies in hypertension, patients with nondipper pattern (that is associated with cardiovascular mortality) presented significantly higher mean NLR than those with dipper pattern $(3.1 \pm 0.95$ vs $1.8 \pm 0.52$, $P<0.001) .{ }^{40}$ NLR is also associated with resistant hypertension ${ }^{41}$ and other risk factors for atherosclerosis such as metabolic syndrome ${ }^{42}$ and diabetes. ${ }^{43}$ Table 1 summarizes the clinical studies on the predictive value of inflammatory biomarkers in cardiovascular outcomes.

\section{Inflammatory markers in PAD}

Several studies have demonstrated the association between inflammatory markers and the incidence, severity, response to treatment, and prognosis of PAD. ${ }^{44}{ }^{47} \mathrm{CRP}$ was, in a cohort, the strongest nonlipidic predictor of PAD (relative risk [RR] 2.8 for the highest quartile in comparison to the lowest). ${ }^{44}$ In other studies, the CRP was a significant predictor of major adverse limb events (target vessel revascularization, amputation, or disease progression) and major cardiovascular events in patients with PAD who have undergone angioplasty or stent ${ }^{47}$ and a predictor of mortality. ${ }^{12,48}$

In patients being treated with statins for $\mathrm{PAD}$, the benefit of reducing mortality from all causes and CVD was only significant in those with baseline CRP above the median and not in those with baseline CRP below the median 

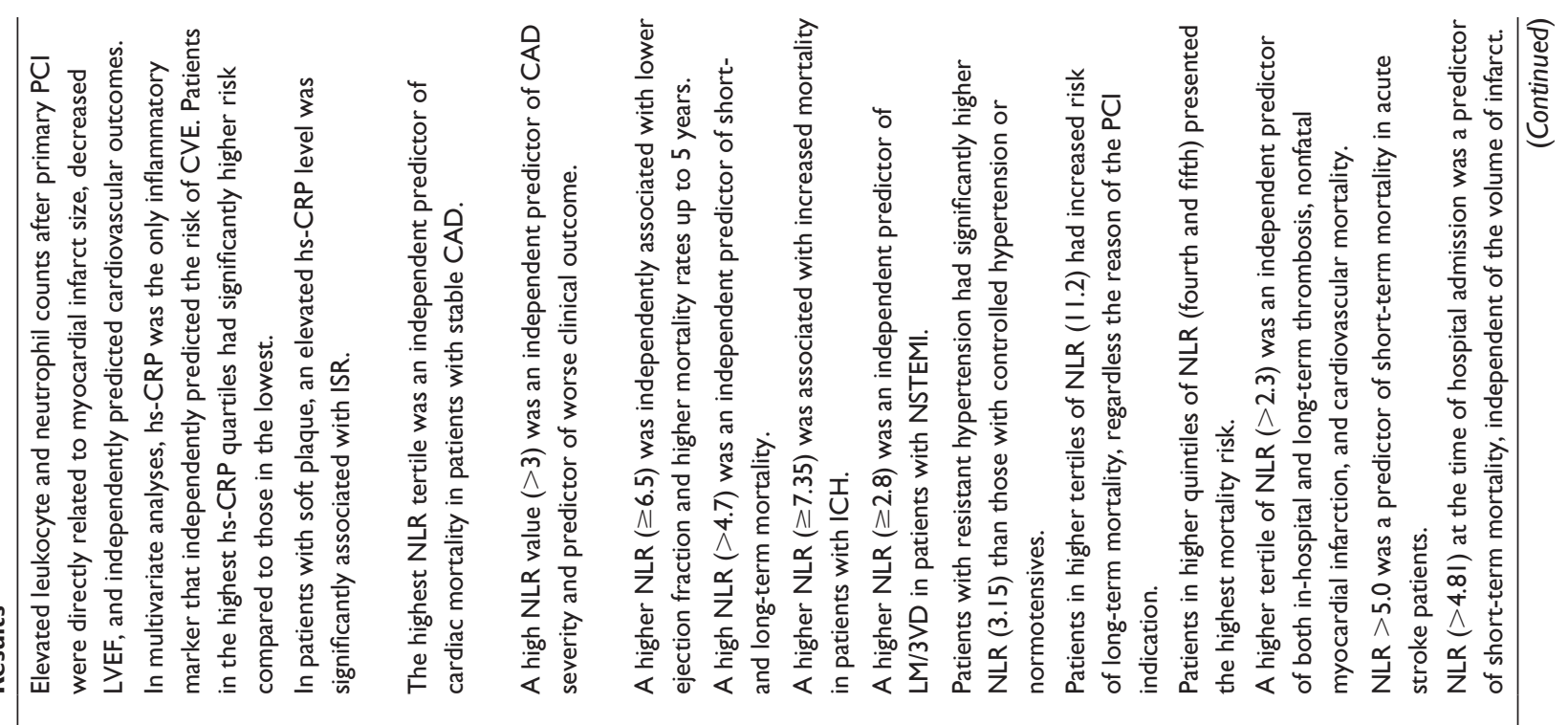

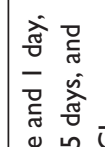

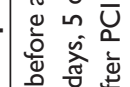

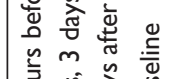

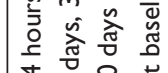

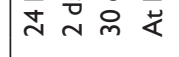
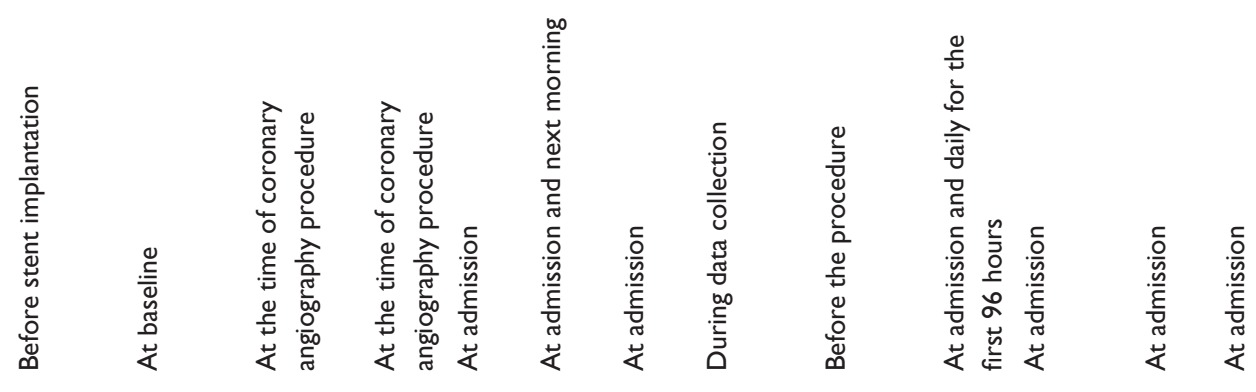

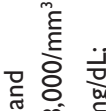

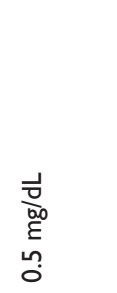

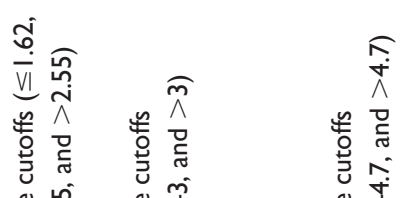

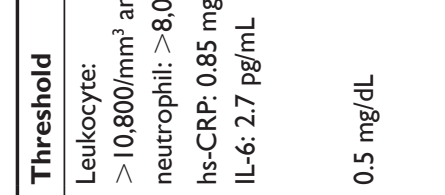

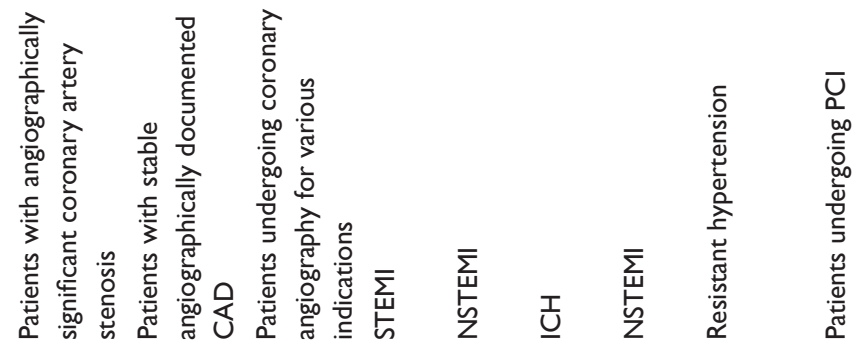

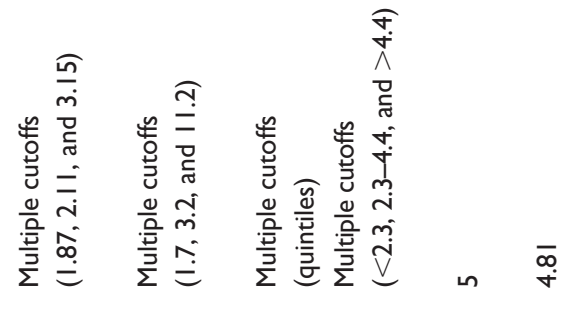

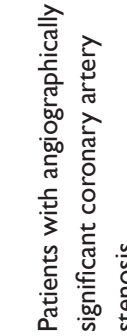




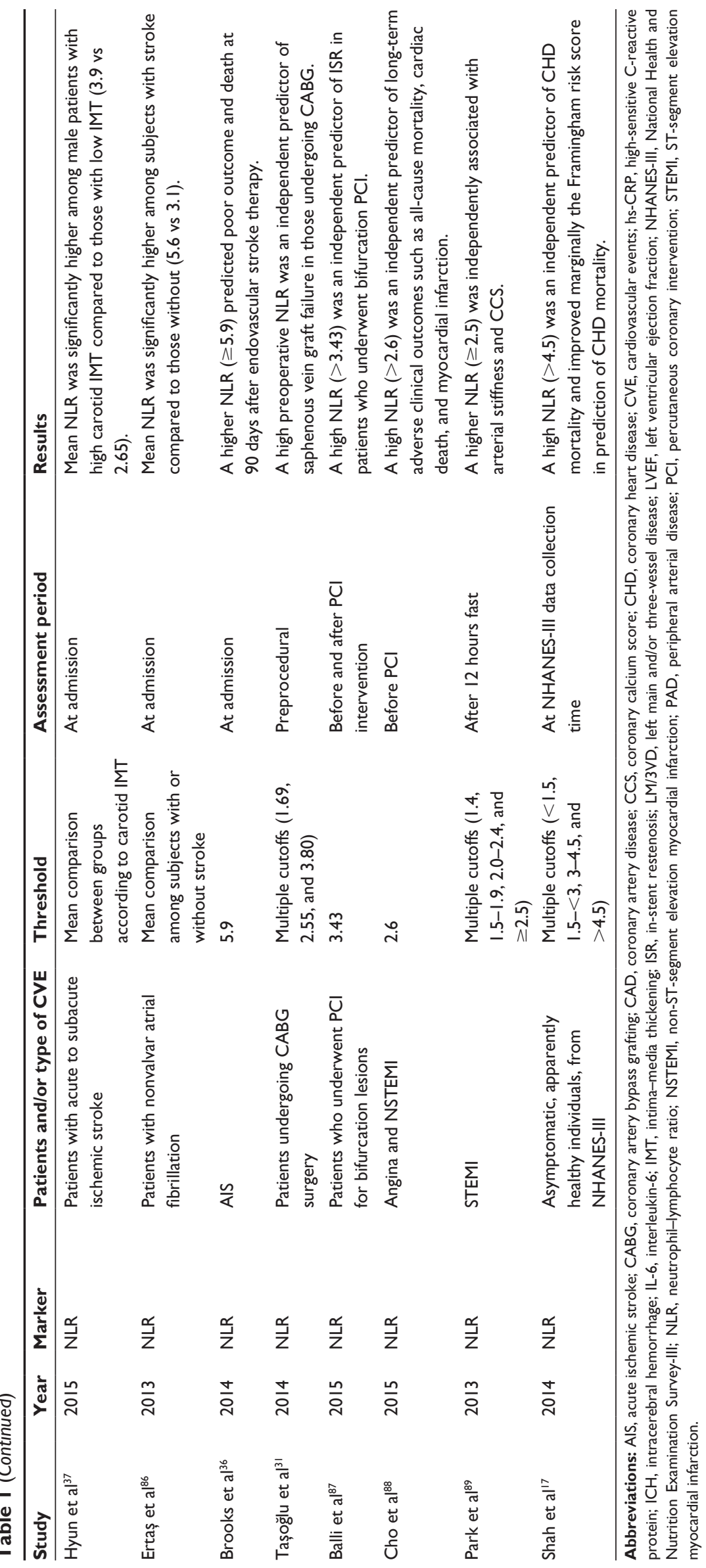


(HR $0.44 ; 95 \%$ CI $0.23-0.88$ vs HR $0.73 ; 95 \%$ CI $0.31-1.75$ ). ${ }^{13}$ This result suggests that the benefit of statin is closely related to their anti-inflammatory effect, which is in accordance with the findings in patients with $\mathrm{CAD}$, in which the benefit of statins in survival occurs mainly in subjects with high initial CRP, with fall during treatment, independent of lipid level. ${ }^{49,50} \mathrm{It} \mathrm{has}$ also been evident in the finding that statin mitigated plaque inflammation, measured by noninvasive imaging with $18 \mathrm{~F}$ fluorodeoxyglucose positron emission tomography..$^{51,52}$ And, even in apparently healthy individuals, with elevated baseline high-sensitive CRP, treatment with statin reduced significantly the incidence of major cardiovascular events. ${ }^{53}$

Another inflammatory marker associated with PAD and its progression is the IL- $6{ }^{46,54}$ In a cohort of 12 years of follow-up, IL-6 was the inflammatory marker that showed the strongest and consistent predictive value for progression of PAD. ${ }^{54}$ And, in patients with established PAD, persistently high IL-6 levels are associated with faster functional decline $^{25}$ and greater severity of disease with critical limb ischemia (CLI). ${ }^{46}$ Table 2 summarizes the clinical studies on the predictive value of general inflammatory biomarkers (other than NLR) in PAD.

\section{The particular role of NLR as a prognostic marker in PAD PAD severity}

In PAD, a high NLR is associated with increased severity of disease, ${ }^{55,56}$ as was evident in a retrospective cohort of 2,121 patients with PAD in which CLI occurred significantly more in the group with a high NLR $(48.5 \%$ vs $24.3 \%$, $P<0.001) .{ }^{56}$ In another study including 1,995 patients with PAD, the increase in NLR was associated with a significant increase in CLI rates $(20.4 \%, 26.1 \%$, and $36.1 \%$ for the first, second, and third tertiles, respectively). ${ }^{55}$

\section{Response to treatment and prognosis}

In patients who initially received conservative therapy for CLI, a high NLR was an independent predictive factor for amputation and was associated with lower amputation-free survival. ${ }^{57,58} \mathrm{~A}$ high NLR was a risk factor for amputation within 30 days in patients who underwent initial embolectomy for acute limb ischemia ${ }^{31}$ and an independent predictor of graft failure (occlusion or ipsilateral amputation) in those undergoing infrainguinal bypass grafting. ${ }^{59}$

\section{Mortality}

A high NLR not only predicts disease severity and response to treatment but also is a predictor of mortality. ${ }^{60}$ In patients followed for PAD, a high NLR predicted independently long-term cardiovascular mortality (HR 2.04, $P=0.004$ ) ${ }^{60}$ A high NLR at admission for chronic CLI is associated with increased mortality. ${ }^{61}$

In treated patients, a high pre-intervention NLR was an independent predictor of mortality in those who have undergone infrapopliteal percutaneous intervention for CLI (HR 1.95, $P<0.03$ ). ${ }^{62}$ And, even in those undergoing elective revascularization, a high preoperative NLR was independently associated with increased mortality ${ }^{63,64}$ Table 3 summarizes the clinical studies that have assessed the role of NLR as a prognostic biomarker in PAD.

\section{Potential mechanism underlying NLR role in PAD and atherosclerosis in general}

Despite substantial epidemiological evidence of the predictive role of NLR in atherosclerotic manifestations, there is a lack of pathophysiological body for such findings. This derived marker is an imbalance of inflammatory cells (disproportionate dominance of neutrophils over lymphocytes), and it may be a reflection of a deeper imbalance in the immunologic response, with the dominance of effectors cells over the regulatory cells, mainly CD4 ${ }^{+} \mathrm{T}$-helper cells. ${ }^{65,66}$ Some studies have described the domain of subtype T-helper 17 over the regulatory T-cells, resulting in the activation of the interleukin-17 axis that is in turn associated with vascular dysfunction, progression of atherosclerosis, and vascular events. ${ }^{65,67,68}$ Several other mechanisms may be involved in the link between NLR and atherosclerosis, including endothelial dysfunction ${ }^{69,70}$ and oxidative stress. ${ }^{71}$ However, in light of the current literature, there are no sufficient data to support the formulation of a conceptual or pathophysiologic model linking the two. Despite this gap, we know that atherosclerosis is mainly an inflammatory disease, ${ }^{72}$ and currently effective therapies, particularly statins, are associated with decreasing inflammatory response. ${ }^{49,51,52,73}$ The most accurate understanding of the mechanisms underlying this emerging evidence from clinical studies should be a substrate of a call to action for future studies in basic science, translational, experimental, and clinical levels.

\section{Concerns and limitations of the NLR as a cardiovascular biomarker}

Some concerns arise regarding the potential use of NLR as a cardiovascular biomarker. NLR is increased in other situations such as nonalcoholic fatty liver disease, metabolic syndrome, psoriasis, and cancer. ${ }^{42,74,75}$ All these conditions share in common an inflammatory or immune response in a given point of their pathogenesis, and interestingly, most of these have been also associated with CVDs as described 


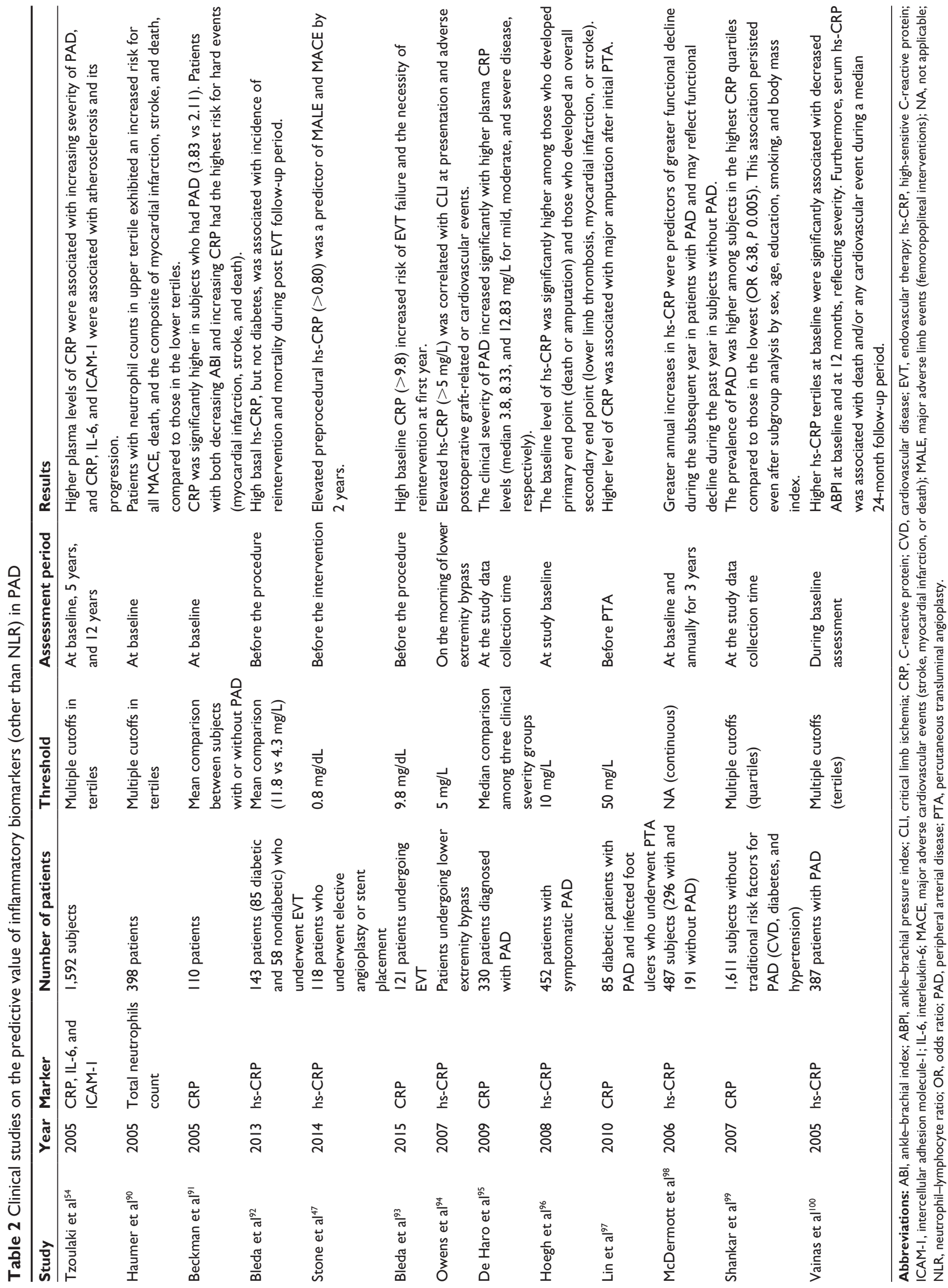


Table 3 Clinical studies on the role of NLR as prognostic biomarkers in PAD

\begin{tabular}{|c|c|c|c|c|c|}
\hline Study & Year & $\begin{array}{l}\text { Number } \\
\text { of patients }\end{array}$ & Threshold & $\begin{array}{l}\text { Assessment } \\
\text { period }\end{array}$ & Results \\
\hline $\begin{array}{l}\text { Tașoğlu } \\
\text { et al|101 }\end{array}$ & 2014 & 254 & 5.2 & At admission & $\begin{array}{l}\text { A higher NLR }(\geq 5.2) \text { was a risk factor for amputation within } 30 \text { days after } \\
\text { surgery in patients who underwent embolectomy for acute limb ischemia. }\end{array}$ \\
\hline Kullar et $\mathrm{a}^{59}$ & 2012 & 126 & NA & Postoperative & $\begin{array}{l}\text { A higher NLR was an independent predictor of graft failure (occlusion or } \\
\text { ipsilateral amputation) after infrainguinal bypass grafting. }\end{array}$ \\
\hline Belaj et al ${ }^{55}$ & 2015 & 1,995 & 2.5 & $\begin{array}{l}\text { At the study data } \\
\text { collection time }\end{array}$ & $\begin{array}{l}\text { Increased rate of CLI was observed with increasing NLR tertiles ( } 20.4 \% \text {, } \\
26.1 \% \text {, and } 36.1 \% \text { for the lowest, second, and third tertiles, respectively). }\end{array}$ \\
\hline Spark et al ${ }^{61}$ & 2010 & 149 & 5.25 & At admission & $\begin{array}{l}\text { A higher NLR ( } \geq 5.25) \text { was independently associated with shorter survival in } \\
\text { patients being treated for } C L I \text {. }\end{array}$ \\
\hline Erturk et $\mathrm{a}^{160}$ & 2014 & 593 & 3 & $\begin{array}{l}\text { At the study data } \\
\text { collection time }\end{array}$ & $\begin{array}{l}\text { A higher NLR }(>3) \text { was found to predict independently long-term } \\
\text { cardiovascular mortality in patients with intermittent claudication and CLI. }\end{array}$ \\
\hline $\begin{array}{l}\text { González- } \\
\text { Fajardo et al }{ }^{63}\end{array}$ & 2014 & 561 & 5 & At admission & $\begin{array}{l}\text { A higher NLR }(>5) \text { was associated with higher } 5 \text {-year mortality and lower } \\
\text { AFS in patients with chronic CLI who underwent elective infrainguinal open } \\
\text { or endovascular revascularization. }\end{array}$ \\
\hline Tașoğlu et a $\left.\right|^{58}$ & 2014 & 104 & 3.2 & At admission & $\begin{array}{l}\text { A higher NLR }(\geq 3.2) \text { was a good predictor of lower overall limb survival in } \\
\text { patients with nonreconstructable CLI. }\end{array}$ \\
\hline Chan et $a^{62}$ & 2014 & 83 & 5.25 & $\begin{array}{l}\text { Before the } \\
\text { procedure }\end{array}$ & $\begin{array}{l}\text { Patients with a higher NLR }(\geq 5.25) \text { had an increased risk of death after } \\
\text { infrapopliteal percutaneous angioplasty. }\end{array}$ \\
\hline Bhutta et $a^{164}$ & 2011 & $|, 02|$ & 5 & $\begin{array}{l}\text { Before the } \\
\text { surgery }\end{array}$ & $\begin{array}{l}\text { A high preoperative NLR }(>5) \text { was independently associated with mortality } \\
\text { (OR } 2.21 \text { ) within } 2 \text { years after elective major vascular surgery. }\end{array}$ \\
\hline Gary et al ${ }^{56}$ & 2013 & 2,121 & 3.95 & At admission & $\begin{array}{l}\text { In patients with PAOD, an increased NLR }(>3.95) \text { was significantly associated } \\
\text { with } C L I \text { and other vascular end points (myocardial infarction and stroke). }\end{array}$ \\
\hline Luo et $\mathrm{al}^{57}$ & 2015 & 172 & 3.8 & Posttreatment & $\begin{array}{l}\text { A higher NLR }(\geq 3.8) \text {, the posttreatment NLR, was identified as an } \\
\text { independent predictive factor for amputation in patients who receive at first } \\
\text { conservative therapy. }\end{array}$ \\
\hline
\end{tabular}

Abbreviations: AFS, amputation-free survival; CLI, critical limb ischemia; NA, not applicable; NLR, neutrophil-lymphocyte ratio; OR, odds ratio; PAD, peripheral arterial disease; PAOD, peripheral arterial occlusive disease.

by Ganzetti et $\mathrm{al}^{76}$ in his recent review. Despite being a nonspecific marker, NLR has shown consistency in predicting outcomes in atherosclerotic diseases, ${ }^{16-19,23,33-36,58-60}$ and even in the nationally representative sample of American subjects, NLR was significantly higher in those who reported diabetes, CVD, and smoking than in subjects who did not. ${ }^{23}$ In addition, NLR has a good correlation with other inflammatory markers such as CRP, ${ }^{77}$ presenting even better performance as a biomarker in specific conditions. ${ }^{78}$

There are some important limitations of this study. The first is the use of different cutoff values in different studies and the scarcity of published works validating the normality value in the general population. However, as we just underlined, most studies in atherosclerosis found a higher cutoff than the average NLR value (2.15) found in the only existing study in the general population, ${ }^{23}$ which suggests the plausibility of the association found in those studies. The second is the absence of studies that have validated the normality value for specific populations. This point is critical because as a derived ratio, it is, of course, affected by changes either in the numerator or the denominator. For example, subjects who have a relative constitutional lymphopenia would easily be classified as having a high NLR, without necessarily an increased inflammatory activity. So, it is prone to potential bias that could lead to false-positive associations. The third is relative to the paucity of studies clarifying the mechanisms underlying the association between NLR and atherosclerosis.

\section{Conclusion and future directions}

From the available evidence, it is very likely that the presence of a high NLR has predictive value for future vascular events in asymptomatic and symptomatic subjects. This simple, fast, and widely available biomarker can offer an additional noninvasive tool for risk stratification to assess the severity, response to treatment and prognosis of PAD.

More studies are necessary to know and clarify the role of NLR as an additional tool in PAD. This is reinforced because its role has been reproducible and consistent in other vascular beds as cerebral and coronary, especially in the current scenario of growing recognition of various diseases, with chronic inflammatory component as risk factors for atherosclerosis.

Further studies should be addressed to establish the normality value for specific populations to clarify the underlying mechanisms in atherogenesis and should be designed to 
assess the effectiveness of anti-inflammatory therapies using the fall of NLR as a surrogate outcome and assess its role to guide therapy.

\section{Disclosure}

The authors report no conflicts of interest in this work.

\section{References}

1. Fowkes FG, Rudan D, Rudan I, et al. Comparison of global estimates of prevalence and risk factors for peripheral artery disease in 2000 and 2010: a systematic review and analysis. Lancet. 2013;382(9901): 1329-1340.

2. Criqui MH, McClelland RL, McDermott MM, et al. The ankle-brachial index and incident cardiovascular events in the MESA (Multi-Ethnic Study of Atherosclerosis). J Am Coll Cardiol. 2010;56(18):1506-1512.

3. Resnick HE, Lindsay RS, McDermott MM, et al. Relationship of high and low ankle brachial index to all-cause and cardiovascular disease mortality: the Strong Heart Study. Circulation. 2004;109(6):733-739.

4. Fowkes FG, Murray GD, Butcher I, et al. Ankle brachial index combined with Framingham Risk Score to predict cardiovascular events and mortality: a meta-analysis. JAMA. 2008;300(2):197-208.

5. Welten GM, Schouten O, Hoeks SE, et al. Long-term prognosis of patients with peripheral arterial disease: a comparison in patients with coronary artery disease. J Am Coll Cardiol. 2008;51(16):1588-1596.

6. Kornowski R, Hong MK, Tio FO, Bramwell O, Wu H, Leon MB. In-stent restenosis: contributions of inflammatory responses and arterial injury to neointimal hyperplasia. J Am Coll Cardiol. 1998;31(1):224-230.

7. Schillinger M, Exner M, Mlekusch W, et al. Vascular inflammation and percutaneous transluminal angioplasty of the femoropopliteal artery: association with restenosis. Radiology. 2002;225(1):21-26.

8. Minar E, Pokrajac B, Maca T, et al. Endovascular brachytherapy for prophylaxis of restenosis after femoropopliteal angioplasty: results of a prospective randomized study. Circulation. 2000;102(22):2694-2699.

9. Hansson GK. Inflammation, atherosclerosis, and coronary artery disease. N Engl J Med. 2005;352(16):1685-1695.

10. Libby P. Inflammation and atherosclerosis. Circulation. 2002;105(9): 1135-1143.

11. Rein P, Saely CH, Silbernagel G, et al. Systemic inflammation is higher in peripheral artery disease than in stable coronary artery disease. Atherosclerosis. 2015;239(2):299-303.

12. Criqui MH, Ho LA, Denenberg JO, Ridker PM, Wassel CL, McDermott MM. Biomarkers in peripheral arterial disease patients and near- and longer-term mortality. J Vasc Surg. 2010;52(1):85-90.

13. Vidula H, Tian L, Liu K, et al. Comparison of effects of statin use on mortality in patients with peripheral arterial disease with versus without elevated C-reactive protein and d-dimer levels. Am J Cardiol. 2010;105(9):1348-1352.

14. van Wijk DF, Boekholdt SM, Wareham NJ, et al. C-reactive protein, fatal and nonfatal coronary artery disease, stroke, and peripheral artery disease in the prospective EPIC-Norfolk cohort study. Arterioscler Thromb Vasc Biol. 2013;33(12):2888-2894.

15. Kaptoge S, Di Angelantonio E, Lowe G, et al. C-reactive protein concentration and risk of coronary heart disease, stroke, and mortality: an individual participant meta-analysis. Lancet. 2010;375(9709):132-140.

16. Meissner J, Irfan A, Twerenbold R, et al. Use of neutrophil count in early diagnosis and risk stratification of AMI. Am J Med. 2011;124(6): 534-542.

17. Shah N, Parikh V, Patel N, et al. Neutrophil lymphocyte ratio significantly improves the Framingham risk score in prediction of coronary heart disease mortality: insights from the National Health and Nutrition Examination Survey-III. Int J Cardiol. 2014;171(3):390-397.

18. Tamhane UU, Aneja S, Montgomery D, Rogers E-K, Eagle KA, Gurm HS. Association between admission neutrophil to lymphocyte ratio and outcomes in patients with acute coronary syndrome. Am J Cardiol. 2008;102(6):653-657.
19. Papa A, Emdin M, Passino C, Michelassi C, Battaglia D, Cocci F. Predictive value of elevated neutrophil-lymphocyte ratio on cardiac mortality in patients with stable coronary artery disease. Clin Chim Acta. 2008; 395(1-2):27-31.

20. Akpek M, Kaya MG, Lam YY, et al. Relation of neutrophil/lymphocyte ratio to coronary flow to in-hospital major adverse cardiac events in patients with ST-elevated myocardial infarction undergoing primary coronary intervention. Am J Cardiol. 2012;110(5):621-627.

21. Baetta R, Corsini A. Role of polymorphonuclear neutrophils in atherosclerosis: current state and future perspectives. Atherosclerosis. 2010;210(1): $1-13$.

22. Balta S, Celik T, Mikhailidis DP, et al. The relation between atherosclerosis and the neutrophil-lymphocyte ratio. Clin Appl Thromb Hemost. Epub 2015 Feb 9.

23. Azab B, Camacho-Rivera M, Taioli E. Average values and racial differences of neutrophil lymphocyte ratio among a nationally representative sample of United States subjects. PLoS One. 2014;9(11):e112361.

24. Ridker PM, Hennekens CH, Buring JE, Rifai N. C-reactive protein and other markers of inflammation in the prediction of cardiovascular disease in women. $N$ Engl J Med. 2000;342(12):836-843.

25. McDermott MM, Liu K, Ferrucci L, et al. Relation of interleukin-6 and vascular cellular adhesion molecule-1 levels to functional decline in patients with lower extremity peripheral arterial disease. Am J Cardiol. 2011;107(9):1392-1398.

26. Danesh J, Wheeler JG, Hirschfield GM, et al. C-reactive protein and other circulating markers of inflammation in the prediction of coronary heart disease. N Engl J Med. 2004;350(14):1387-1397.

27. Arbel Y, Finkelstein A, Halkin A, et al. Neutrophil/lymphocyte ratio is related to the severity of coronary artery disease and clinical outcome in patients undergoing angiography. Atherosclerosis. 2012;225(2): 456-460.

28. Azab B, Zaher M, Weiserbs KF, et al. Usefulness of neutrophil to lymphocyte ratio in predicting short- and long-term mortality after non-STelevation myocardial infarction. Am J Cardiol. 2010;106(4):470-476.

29. Arbel Y, Shacham Y, Ziv-Baran T, et al. Higher neutrophil/lymphocyte ratio is related to lower ejection fraction and higher long-term all-cause mortality in ST-elevation myocardial infarction patients. Can J Cardiol. 2014;30(10):1177-1182.

30. Turak O, Ozcan F, Isleyen A, et al. Usefulness of the neutrophil-tolymphocyte ratio to predict bare-metal stent restenosis. Am J Cardiol. 2012;110(10):1405-1410.

31. Taşoğlu I, Turak O, Nazli Y, et al. Preoperative neutrophil-lymphocyte ratio and saphenous vein graft patency after coronary artery bypass grafting. Clin Appl Thromb Hemost. 2014;20(8):819-824.

32. Gibson PH, Croal BL, Cuthbertson BH, et al. Preoperative neutrophillymphocyte ratio and outcome from coronary artery bypass grafting. Am Heart J. 2007;154(5):995-1002.

33. Wang X, Zhang G, Jiang X, Zhu H, Lu Z, Xu L. Neutrophil to lymphocyte ratio in relation to risk of all-cause mortality and cardiovascular events among patients undergoing angiography or cardiac revascularization: a meta-analysis of observational studies. Atherosclerosis. 2014; 234(1):206-213.

34. Tokgoz S, Keskin S, Kayrak M, Seyithanoglu A, Ogmegul A. Is neutrophil/ lymphocyte ratio predict to short-term mortality in acute cerebral infarct independently from infarct volume? J Stroke Cerebrovasc Dis. 2014; 23(8):2163-2168.

35. Wang F, Hu S, Ding Y, et al. Neutrophil-to-lymphocyte ratio and 30-day mortality in patients with acute intracerebral hemorrhage. J Stroke Cerebrovasc Dis. 2016;25(1):182-187.

36. Brooks SD, Spears C, Cummings C, et al. Admission neutrophillymphocyte ratio predicts 90 day outcome after endovascular stroke therapy. J Neurointerv Surg. 2014;6(8):578-583.

37. Hyun S, Kwon S, Cho S, et al. Can the neutrophil-to-lymphocyte ratio appropriately predict carotid artery stenosis in patients with ischemic stroke?-A retrospective study. J Stroke Cerebrovasc Dis. 2015;24(11):2646-2651.

38. Gökhan S, Ozhasenekler A, Mansur Durgun H, Akil E, Ustündag M, Orak M. Neutrophil lymphocyte ratios in stroke subtypes and transient ischemic attack. Eur Rev Med Pharmacol Sci. 2013;17(5):653-657. 
39. Liu X, Zhang Q, Wu H, et al. Blood neutrophil to lymphocyte ratio as a predictor of hypertension. Am J Hypertens. 2015;28(11): 1339-1346.

40. Demir M. The relationship between neutrophil lymphocyte ratio and non-dipper hypertension. Clin Exp Hypertens. 2013;35(8): 570-573.

41. Belen E, Sungur A, Sungur MA, Erdoğan G. Increased neutrophil to lymphocyte ratio in patients with resistant hypertension. J Clin Hypertens (Greenwich). 2015;17(7):532-537.

42. Buyukkaya E, Karakas MF, Karakas E, et al. Correlation of neutrophil to lymphocyte ratio with the presence and severity of metabolic syndrome. Clin Appl Thromb Hemost. 2014;20(2):159-163.

43. Yilmaz H, Ucan B, Sayki M, et al. Usefulness of the neutrophil-tolymphocyte ratio to prediction of type 2 diabetes mellitus in morbid obesity. Diabetes Metab Syndr. 2015;9(4):299-304.

44. Ridker PM, Stampfer MJ, Rifai N. Novel risk factors for systemic atherosclerosis: a comparison of C-reactive protein, fibrinogen, homocysteine, lipoprotein(a), and standard cholesterol screening as predictors of peripheral arterial disease. JAMA. 2001;285(19):2481-2485.

45. Brevetti G, Giugliano G, Brevetti L, Hiatt WR. Inflammation in peripheral artery disease. Circulation. 2010;122(18):1862-1875.

46. Danielsson P, Truedsson L, Eriksson K-F, Norgren L. Inflammatory markers and IL-6 polymorphism in peripheral arterial disease with and without diabetes mellitus. Vasc Med. 2005;10(3):191-198.

47. Stone PA, Schlarb H, Campbell JE, et al. C-reactive protein and brain natriuretic peptide as predictors of adverse events after lower extremity endovascular revascularization. J Vasc Surg. 2014;60(3):652-660.

48. Vidula H, Tian L, Liu K, et al. Biomarkers of inflammation and thrombosis as predictors of near-term mortality in patients with peripheral arterial disease: a cohort study. Ann Intern Med. 2008;148(2):85-93.

49. Horne BD, Muhlestein JB, Carlquist JF, et al. Statin therapy, lipid levels, C-reactive protein and the survival of patients with angiographically severe coronary artery disease. J Am Coll Cardiol. 2000;36(6) 1774-1780.

50. Ridker PM, Cannon CP, Morrow D, et al. C-reactive protein levels and outcomes after statin therapy. $N$ Engl J Med. 2005;352(1):20-28.

51. Tahara N, Kai H, Ishibashi M, et al. Simvastatin attenuates plaque inflammation: evaluation by fluorodeoxyglucose positron emission tomography. J Am Coll Cardiol. 2006;48(9):1825-1831.

52. Tawakol A, Fayad ZA, Mogg R, et al. Intensification of statin therapy results in a rapid reduction in atherosclerotic inflammation: results of a multicenter fluorodeoxyglucose-positron emission tomography/ computed tomography feasibility study. J Am Coll Cardiol. 2013; 62(10):909-917.

53. Ridker PM, Danielson E, Fonseca FA, et al. Rosuvastatin to prevent vascular events in men and women with elevated C-reactive protein. N Engl J Med. 2008;359(21):2195-2207.

54. Tzoulaki I, Murray GD, Lee AJ, Rumley A, Lowe GD, Fowkes GR. C-reactive protein, interleukin-6, and soluble adhesion molecules as predictors of progressive peripheral atherosclerosis in the general population. Edinburgh Artery Study. ACC Curr J Rev. 2005; 14(12):16.

55. Belaj K, Pichler M, Hackl G, et al. Association of the derived neutrophillymphocyte ratio with critical limb ischemia. Angiology. 2015; 67(4):350-354.

56. Gary T, Pichler M, Belaj K, et al. Neutrophil-to-lymphocyte ratio and its association with critical limb ischemia in PAOD patients. PLoS One. 2013;8(2):e56745.

57. Luo H, Yuan D, Yang H, et al. Post-treatment neutrophil-lymphocyte ratio independently predicts amputation in critical limb ischemia without operation. Clinics (São Paulo). 2015;70(4):273-277.

58. Taşoğlu I, Sert D, Colak N, Uzun A, Songur M, Ecevit A. Neutrophillymphocyte ratio and the platelet-lymphocyte ratio predict the limb survival in critical limb ischemia. Clin Appl Thromb Hemost. 2014;20(6):645-650.

59. Kullar P, Weerakoddy R, Walsh S. Neutrophil-lymphocyte ratio predicts graft patency following lower limb revascularisation. Acta Chir Belg. 2012;112(5):365-368.
60. Erturk M, Cakmak HA, Surgit O, et al. Predictive value of elevated neutrophil to lymphocyte ratio for long-term cardiovascular mortality in peripheral arterial occlusive disease. J Cardiol. 2014;64(5): 371-376.

61. Spark JI, Sarveswaran J, Blest N, Charalabidis P, Asthana S. An elevated neutrophil-lymphocyte ratio independently predicts mortality in chronic critical limb ischemia. J Vasc Surg. 2010;52(3):632-636.

62. Chan C, Puckridge P, Ullah S, Delaney C, Spark JI. Neutrophillymphocyte ratio as a prognostic marker of outcome in infrapopliteal percutaneous interventions for critical limb ischemia. $J$ Vasc Surg. 2014;60(3):661-668.

63. González-Fajardo JA, Brizuela-Sanz JA, Aguirre-Gervás B, et al. Prognostic significance of an elevated neutrophil-lymphocyte ratio in the amputation-free survival of patients with chronic critical limb ischemia. Ann Vasc Surg. 2014;28(4):999-1004.

64. Bhutta H, Agha R, Wong J, Tang TY, Wilson YG, Walsh SR. Neutrophil-lymphocyte ratio predicts medium-term survival following elective major vascular surgery: a cross-sectional study. Vasc Endovascular Surg. 2011;45(3):227-231.

65. Cheng X, Yu X, Ding Y-J, et al. The Th17/Treg imbalance in patients with acute coronary syndrome. Clin Immunol. 2008;127(1): 89-97.

66. Doroudchi M, Nikoo MH, Taghavian SR, Golmoghaddam H, Ardakani AA. Increased IL-17A in atrial fibrillation correlates with neutrophil to lymphocyte ratio. Atherosclerosis. 2015;241(1):e91.

67. Smith E, Prasad K-MR, Butcher M, et al. Blockade of interleukin-17A results in reduced atherosclerosis in apolipoprotein E-deficient mice. Circulation. 2010;121(15):1746-1755.

68. Madhur MS, Lob HE, McCann LA, et al. Interleukin 17 promotes angiotensin II-induced hypertension and vascular dysfunction. Hypertension. 2009;55(2):500-507.

69. Ünlü M, Arslan Z. The relation between neutrophil-lymphocyte ratio and endothelial dysfunction. Angiology. 2015;66(7):694.

70. Turkmen K, Tufan F, Selçuk E, Akpınar T, Oflaz H, Ecder T. Neutrophil-to-lymphocyte ratio, insulin resistance, and endothelial dysfunction in patients with autosomal dominant polycystic kidney disease. Indian J Nephrol. 2013;23(1):34-40.

71. Kotani K. Neutrophil/lymphocyte ratio and the oxidative stress burden Can J Cardiol. 2015;31(3):365.e9.

72. Libby P, Tabas I, Fredman G, Fisher EA. Inflammation and its resolution as determinants of acute coronary syndromes. Circ Res. 2014;114(12): 1867-1879.

73. Puri R, Nissen SE, Libby P, et al. C-reactive protein, but not low-density lipoprotein cholesterol levels, associate with coronary atheroma regression and cardiovascular events after maximally intensive statin therapy. Circulation. 2013;128(22):2395-2403.

74. Walsh SR, Cook EJ, Goulder F, Justin TA, Keeling NJ. Neutrophillymphocyte ratio as a prognostic factor in colorectal cancer. J Surg Oncol. 2005;91(3):181-184.

75. Alkhouri N, Morris-Stiff G, Campbell C, et al. Neutrophil to lymphocyte ratio: a new marker for predicting steatohepatitis and fibrosis in patients with nonalcoholic fatty liver disease. Liver Int. 2012; 32(2):297-302.

76. Ganzetti G, Campanati A, Molinelli E, Offidani A. Psoriasis, nonalcoholic fatty liver disease, and cardiovascular disease: three different diseases on a unique background. World J Cardiol. 2016;8(2): $120-131$.

77. Oh BS, Jang JW, Kwon JH, et al. Prognostic value of C-reactive protein and neutrophil-to-lymphocyte ratio in patients with hepatocellular carcinoma. BMC Cancer. 2013;13(1):78.

78. Yilmaz H, Yalcin KS, Namuslu M, et al. Neutrophil-lymphocyte ratio (NLR) could be better predictor than C-reactive protein (CRP) for liver fibrosis in non-alcoholic steatohepatitis (NASH). Ann Clin Lab Sci. 2015;45(3):278-286.

79. Chia S, Nagurney JT, Brown DF, et al. Association of leukocyte and neutrophil counts with infarct size, left ventricular function and outcomes after percutaneous coronary intervention for ST-elevation myocardial infarction. Am J Cardiol. 2009;103(3):333-337. 
80. Hong YJ, Jeong MH, Lim SY, et al. Relation of soft plaque and elevated preprocedural high-sensitivity $\mathrm{C}$-reactive protein levels to incidence of in-stent restenosis after successful coronary artery stenting. Am J Cardiol. 2006;98(3):341-345.

81. Misumida N, Kobayashi A, Saeed M, Fox JT, Kanei Y. Neutrophilto-lymphocyte ratio as an independent predictor of left main and/ or three-vessel disease in patients with non-ST-segment elevation myocardial infarction. Cardiovasc Revasc Med. 2015;16(6): $331-335$.

82. Duffy BK, Gurm HS, Rajagopal V, Gupta R, Ellis SG, Bhatt DL. Usefulness of an elevated neutrophil to lymphocyte ratio in predicting long-term mortality after percutaneous coronary intervention. Am J Cardiol. 2006;97(7):993-996.

83. Núñez J, Núñez E, Bodí V, et al. Usefulness of the neutrophil to lymphocyte ratio in predicting long-term mortality in ST segment elevation myocardial infarction. Am J Cardiol. 2008;101(6): 747-752.

84. Kaya MG, Akpek M, Lam YY, et al. Prognostic value of neutrophil/ lymphocyte ratio in patients with ST-elevated myocardial infarction undergoing primary coronary intervention: a prospective, multicenter study. Int J Cardiol. 2013;168(2):1154-1159.

85. Tokgoz S, Kayrak M, Akpinar Z, Seyithanoğlu A, Güney F, Yürüten B. Neutrophil lymphocyte ratio as a predictor of stroke. J Stroke Cerebrovasc Dis. 2013;22(7):1169-1174.

86. Ertaş G, Sönmez O, Turfan M, et al. Neutrophil/lymphocyte ratio is associated with thromboembolic stroke in patients with non-valvular atrial fibrillation. J Neurol Sci. 2013;324(1-2):49-52.

87. Balli M, Taşolar H, Çetin M, et al. Use of the neutrophil to lymphocyte ratio for prediction of in-stent restenosis in bifurcation lesions. Eur Rev Med Pharmacol Sci. 2015;19(10):1866-1873.

88. Cho KI, Ann SH, Singh GB, Her A-Y, Shin E-S. Combined usefulness of the platelet-to-lymphocyte ratio and the neutrophil-to-lymphocyte ratio in predicting the long-term adverse events in patients who have undergone percutaneous coronary intervention with a drug-eluting stent. PLoS One. 2015;10(7): 0133934.

89. Park B-J, Shim J-Y, Lee H-R, et al. Corrigendum to "Relationship of neutrophil-lymphocyte ratio with arterial stiffness and coronary calcium score" published in Clinica Chimica Acta 412/11-12 (2011) 925-929. Clin Chim Acta. 2013;425:265.

90. Haumer M, Amighi J, Exner M, et al. Association of neutrophils and future cardiovascular events in patients with peripheral artery disease. J Vasc Surg. 2005;41(4):610-617.
91. Beckman JA, Preis O, Ridker PM, Gerhard-Herman M. Comparison of usefulness of inflammatory markers in patients with versus without peripheral arterial disease in predicting adverse cardiovascular outcomes (myocardial infarction, stroke, and death). Am J Cardiol. 2005; 96(10):1374-1378.

92. Bleda S, de Haro J, Varela C, Lopez de Maturana I, Rodriguez J, Acin F. Inflammatory burden but not diabetes mellitus influences in prognosis of endovascular revascularization in peripheral arterial disease. ISRN Vasc Med. 2013;2013:1-7.

93. Bleda S, de Haro J, Varela C, Acin F. C-reactive protein and endovascular treatment of lower limb peripheral artery disease: an independent prognostic factor. J Endovasc Ther. 2015;22(2):233-239.

94. Owens CD, Ridker PM, Belkin M, et al. Elevated C-reactive protein levels are associated with postoperative events in patients undergoing lower extremity vein bypass surgery. J Vasc Surg. 2007;45(1):2-9; discussion 9.

95. De Haro J, Acin F, Medina FJ, Lopez-Quintana A, March JR. Relationship between the plasma concentration of C-reactive protein and severity of peripheral arterial disease. Clin Med Cardiol. 2009;3:1-7.

96. Hoegh AL, Joensen J, Lindholt JS, Jacobsen MR, Ostergaard L. $\mathrm{C}$-reactive protein predicts future arterial and cardiovascular events in patients with symptomatic peripheral arterial disease. Vasc Endovascular Surg. 2008;42(4):341-347.

97. Lin C-W, Hsu L-A, Chen C-C, et al. C-reactive protein as an outcome predictor for percutaneous transluminal angioplasty in diabetic patients with peripheral arterial disease and infected foot ulcers. Diabetes Res Clin Pract. 2010;90(2):167-172.

98. McDermott MM, Liu K, Guralnik JM, et al. Functional decline in patients with and without peripheral arterial disease: predictive value of annual changes in levels of C-reactive protein and D-dimer. J Gerontol A Biol Sci Med Sci. 2006;61(4):374-379.

99. Shankar A, Li J, Nieto FJ, Klein BEK, Klein R. Association between $\mathrm{C}$-reactive protein level and peripheral arterial disease among US adults without cardiovascular disease, diabetes, or hypertension. Am Heart J. 2007;154(3):495-501.

100. Vainas T, Stassen FRM, de Graaf R, et al. C-reactive protein in peripheral arterial disease: relation to severity of the disease and to future cardiovascular events. J Vasc Surg. 2005;42(2):243-251.

101. Taşoğlu I, Çiçek OF, Lafci G, et al. Usefulness of neutrophil/lymphocyte ratio as a predictor of amputation after embolectomy for acute limb ischemia. Ann Vasc Surg. 2014;28(3):606-613.
Therapeutics and Clinical Risk Management

\section{Publish your work in this journal}

Therapeutics and Clinical Risk Management is an international, peerreviewed journal of clinical therapeutics and risk management, focusing on concise rapid reporting of clinical studies in all therapeutic areas, outcomes, safety, and programs for the effective, safe, and sustained use of medicines. This journal is indexed on PubMed Central, CAS,

\section{Dovepress}

EMBase, Scopus and the Elsevier Bibliographic databases. The manuscript management system is completely online and includes a very quick and fair peer-review system, which is all easy to use. Visit http://www.dovepress.com/testimonials.php to read real quotes from published authors. 